The Canadian Journal of Higher Education, Vol. XXIII-3, 1993

La revue canadienne d'enseignement supérieur, Vol. XXIII-3, 1993

\title{
Towards Reform in Subject-Matter Preparation of Science Teachers: Collaboration Between a Faculty of Science and a Faculty of Education
}

\section{MARGARET McNAY*}

\begin{abstract}
Recent research in the subject-matter preparation of science teachers reveals serious shortcomings in undergraduate programs, particularly their failure to provide students with adequate conceptual understandings, their perpetuation of myths and stereotypes about science and scientists, and their tendency to turn students (particularly women) away from science. In an attempt to alleviate these problems, and to stem declining enrollment in science programs at both secondary and post-secondary levels, the Faculty of Education and the Faculty of Science at the University of Western Ontario are collaborating in the development of a new Honours B.Sc. program. The proposal is for an interdisciplinary program permitting a broader selection of courses and a more comprehensive introduction to science than is offered in current Honours B.Sc. programs. The new program is not intended exclusively or even primarily for prospective teachers but for all students. A proposal for action research and program evaluation is also described.
\end{abstract}

\section{Résumé}

Les recherches récentes sur la formation disciplinaire des professeurs en sciences révèlent des lacunes importantes dans les programmes d'études de baccalauréat, principalement au chapître de la compréhension conceptuelle de la

* University of Western Ontario 
matière, de la perpétuation de mythes et de stéréotypes sur la science et sur les scientistes, et de leurs tendances à éloigner les étudiants, particulièrement les femmes, de la science. Pour tenter de minimiser ces problèmes, et pour contrer la chute des clientèles étudiantes dans les programmes de science aux niveaux secondaire et postsecondaire, les facultés de l'éducation et des sciences de l'Université Western Ontario ont collaboré au développement d'un nouveau programme "Honours" en science. La proposition suggère la création d'un programme interdisciplinaire permettant un plus grand choix de cours et une introduction plus complète aux concepts scientifiques que ce qui est généralement offert dans les programmes établis. Le nouveau programme n'est pas dédié exclusivement, ou même principalement, aux futurs enseignants mais à tous les étudiants. La poursuite active d'un programme de recherche et d'évaluation est également proposée.

Faculties of education are primarily concerned with the preparation of teachers for Canadian schools, with an emphasis in that preparation on educational studies--pedagogical, methodological, philosophical, psychological, political, and so on. No one would argue, however, that teachers also require a grounding in specific subject matter knowledge. Indeed, R.S. Peters (quoted in Ball \& McDiarmid, 1990) has suggested, "If anything is to be regarded as a specific preparation for teaching, priority must be given to a thorough grounding in something to teach" (p. 437).'

The subject-matter preparation of teachers occurs largely in secondary and post-secondary arts and science programs, the latter offered either concurrently with the teacher education program (as in most programs in western Canada and the United States) or prior to it (as is common in central and eastern Canada in post-baccalaureate, "consecutive" teacher education programs). Although the significance of undergraduate programs to the preparation of future teachers might seem self-evident, teacher educators have paid them scant attention. In her analysis of teacher education in the United States, Feiman-Nemser (1990) notes that:

Because teacher educators have not been responsible for teachers' subject-matter preparation, they have tended to ignore the question of what teachers need to know about their subjects...and where that knowledge is acquired. In the case of elementary teaching, many assume that the content is easy to learn or already familiar, because prospective teachers have had it in school themselves. In the case of secondary teaching, majoring in one's teaching field...is supposed to provide adequate subject-matter background. (p. 221) 
Feiman-Nemser's analysis applies as well in Canada to both concurrent and consecutive programs. Further, there is no agreement among teacher educators about what kind of subject-matter knowledge teachers need, or about what it means to know a subject for the purposes of teaching. For their part, instructors in undergraduate programs are almost totally unaware of a growing body of research on students' subject-matter learning, most of it in science and mathematics, which has profound implications for the nature and content of undergraduate programs as well as for teacher education.

Faculty members in arts and science have often come together with professors of education to consider what courses, and how many of them, should be included in programs for prospective teachers. Beyond requiring a minimum number of course credits in specified subject areas, however, faculties of education have by and large been content to leave it to their arts and science colleagues to define courses for subject-matter specialists. Rarely have inter-faculty discussions focussed on a rationale for specialist training, on the philosophies manifested in undergraduate courses, on epistemological assumptions of courses and programs, or on what prospective teachers actually learn (or should learn) from undergraduate studies.

In view of declining enrollment in science at both secondary and post-secondary levels, increasing criticism of science teaching, and escalating public concern about science education, a reconsideration of undergraduate science programs, particularly in light of current research on students' learning in science, seems warranted. Indeed, an attempt at such reconsideration is being made at the University of Western Ontario where the Faculty of Education (which currently offers a one-year, post-baccalaureate B.Ed.) and the Faculty of Science (which offers a variety of four-year Honours programs) have undertaken a unique collaboration in the development of a new, interdisciplinary Honours B.Sc. The new program is not intended exclusively or even primarily for prospective teachers, but for all students interested in a more comprehensive introduction to science than is offered in existing programs. The collaborative effort offers an opportunity to use educational research and expertise in a way that it has rarely been used before: to inform curriculum development--that is, programs, course content, and instruction--in a Faculty of Science.

This paper comments on the need for reform in the subject-matter preparation of teachers, offers a summary of research in this area, and suggests implications of the research for undergraduate programs. It goes on to describe the proposed Honours B.Sc., outline a plan for action research and program evaluation, and comment on the benefits of inter-faculty collaboration. 


\section{The Need for Reform}

Faculties of science play a major role in defining science for the community at large, and in particular for high school science programs (and thereby, to some degree at least, for science teacher education programs). What counts for science in universities becomes recognized in the community as legitimate, or "real," science; what does not count in universities is less valued in other arenas. It is in high school and university science courses that most students acquire, along with subject-matter knowledge, their understanding of the nature of science, and of its epistemological, philosophical, and methodological characteristics. Conceptions (or misconceptions) of science developed by prospective teachers in their early studies are brought to their studies in education and, eventually, to their teaching in classrooms. Thus, in a variety of direct and indirect ways, faculty of science programs influence not only what is taught in the high school programs that precede them and the science teacher education programs that accompany or follow them but, through their effects on prospective teachers, how it is presented and taught, and who teaches it.

Unfortunately, as colleagues in faculties of science are often the first to point out, undergraduate science programs have tended to focus somewhat narrowly on serving the needs of graduate schools in science - on producing specialists who can go on to doctoral studies - at the expense of the interests of a larger part of the community - those who might wish a broader though still rigorous introduction to science. Beginning in high school, decreasing numbers of students are studying science, a decline having to do at least in part with students' experiences in this subject. Studies (to be reviewed in the next section) of what students learn in science courses dramatically demonstrate the often severe shortcomings of those courses, in particular their failure to provide students with adequate conceptual understandings of common topics, their perpetuation of myths and stereotypes about science and scientists, and their tendency to turn students (particularly women) away from science. What is needed, many teacher educators suggest, are programs that are both more epistemologically sound and more pedagogically attuned to how undergraduates learn and acquire conceptual knowledge. It seems likely that such programs would be more attractive and appropriate not only for students wishing to pursue careers in biology, chemistry, and physics, but also for those who would pursue other sciences (such as environmental science or space science) or enter other professions such as law, journalism, business, and public service. Those who are going on to become science teachers should in particular be prepared in their subject area in ways that will enable them eventually to inspire their own students. 


\section{Teachers' Subject-Matter Knowledge}

Common sense suggests that teachers' own knowledge in a subject area, or lack of it, influences what their students learn:

When teachers possess inaccurate information or conceive of knowledge in narrow ways, they may pass on those ideas to their students. They may fail to challenge students' misconceptions; they may use texts uncritically or alter them inappropriately. Subtly, teachers' conceptions of knowledge shape their practice - the kinds of questions they ask, the ideas they reinforce, the sorts of tasks they assign. (Ball \& McDiarmid, 1990, pp. 438-439.)

Ball \& McDiarmid (1990) identify three dimensions of what students learn from subject-matter study:

\section{Substantive Knowledge of the Subject}

Substantive knowledge refers to the conventional content of the field or discipline: specific information, ideas, facts, topics, concepts, theories, and so on. What students come to understand in the way of substantive knowledge from their undergraduate science courses cannot be discerned from an examination of course descriptions, outlines, and syllabi. Studies of what physics students understand about mechanics, for example, reveal the persistence of naive and inaccurate conceptions, even among students majoring in the subject (see, for example, McDermott, 1984; and Champagne, Gunstone, \& Klopfer, 1985). Studies also show that misconceptions abound about other topics in physics such as heat (Harris, 1981), and in mathematics (Clement, Lochhead, \& Monk, 1981), and other areas of science including biology (Brumby, 1981), and chemistry (Gorodetsky \& Hoz, 1985; Cros et al,; 1986). Students can, it seems, engage successfully in science courses without acquiring accurate conceptual understandings of the subject matter. For those science students who go on to become science teachers, the consequence is that misunderstandings are passed on to their students (Linder \& Erickson, 1989).

\section{Knowledge About the Subject}

Knowing a subject includes an understanding of epistemological issues such as "the relative validity and centrality of different ideas or perspectives, the major disagreements within the field..., how claims are justified and validated, and what doing and engaging in the discourse of the field entails" (Ball \& McDiarmid, 1990, p. 440). What teachers understand about their subject affects how they present that subject and how their students come to view the subject. 
Hodson (1986) suggests that during their own science education, teachers internalize a variety of myths about science and scientists that they carry into their own classrooms:

[There they project] a distorted image of science as a neutral activity, propelled only by its own internal logic and functioning independently of socio-historical-economic issues, and a distorted view of scientists as objective, open-minded, unbiased, and possessing an all-powerful and infallible method for ascertaining the truth about the universe. (Hodson, 1986, p. 220)

In a related vein, Geddis (1990) describes what he calls "the tyranny of the right answer: the systematic distortion of scientific knowledge" in high school classrooms. Distorted views of science may be largely responsible for the increasing numbers of students who opt out of science programs at the earliest opportunity. Hodson (1986) again:

'Most science teachers, who are themselves products of a science education system that places a high premium on scientific knowledge and pays lip service to the history and philosophy of science, share with many practicing scientists a scant understanding of the nature of scientific knowledge.' (Association for Science Education, 1979)

There is an urgent need for a reconsideration of the epistemological basis of the science curriculum in the light of contemporary views in the philosophy and sociology of science, and an urgent need for much greater consideration of philosophical issues...(p. 216).

\section{Dispositions Towards the Subject}

Dispositions towards the subject include likes and dislikes for the subject and for particular topics, propensities to follow particular courses of study and not others, and conceptions about one's own capabilities in a subject area (Ball \& McDiarmid, 1990).

Science is commonly viewed as unsuitable for large portions of the population--or, to put it another way, large portions of the population, particularly women, see themselves as unsuited to doing science. Science is perceived by many to be difficult, isolating, boring, uncreative, unimaginative, the source of much that is wrong in the modern world, dangerous, and amoral. Declining enrollment in science courses and, in particular, the propensity for girls and women to abandon science programs, suggest that these unflattering perceptions 
are widespread, and that something about the way science is presented and represented to students is seriously wrong.

The literature on women in science is substantial. The discrimination women encounter as students in science and as scientists is well documented (see, for example, Ainley, 1990; Kahle, 1985). Haggerty (1991) and others (e.g., Erickson \& Erickson, 1984) describe gender bias in science in Canadian schools and its effect on girls' participation in science programs. The social structure of science that controls access to the field, the existence of deeply rooted masculine biases in the sciences, and the abuses of science and technology that adversely affect women, are well documented themes that have led to a variety of feminist critiques of the sociology and epistemology of science (see, for example, Harding \& O'Barr, 1987; and Keller, 1985).

\section{Implications for Undergraduate Science Programs}

Research on the acquisition of subject-matter knowledge in science has profoundly affected the content and focus of science teacher education courses in some if not all Canadian faculties of education. In the Faculty of Education at the University of Western Ontario, some preservice science teacher education courses have been revised and a new graduate course created specifically to address issues arising from this research. Implications for the curriculum of undergraduate science programs are equally profound.

\section{Substantive Knowledge in Science}

Instructors in courses largely concerned with substantive knowledge should understand more about how students acquire and develop concepts in science, about the role of naive and common sense conceptions, and about the difference between producing the right answer and understanding a subject conceptually. Instructors should be encouraged to familiarize themselves with research on students' misconceptions, and on pedagogical approaches which might help to deal with those misconceptions. The literature on misconceptions is most extensive in physics and mathematics (see Ball and McDiarmid, 1990, for a review) although some research in other fields is also available.

\section{Knowledge About Science}

Consideration should be given in all science courses to the epistemology of science--to helping students develop understandings of the nature of scientific knowledge and method. Such understanding might help to alleviate some of the more common distortions and myths about science and scientists that are formed when substantive knowledge alone is emphasized. 
Courses on the philosophy, sociology, and history of science would be an appropriate part of every science student's program, although such courses probably cannot do as much to establish a view of science in students' minds as can the many other courses students encounter in a program. Instructors in all courses, therefore, should be encouraged to reflect on the philosophy of science portrayed in their discourse, textbooks, course content, materials, laboratory activities, assignments, and evaluation procedures, and through what is emphasized (and not emphasized) in their courses. All instructors should be encouraged to consider to what degree students in their courses might perceive science as a linear process, an objective, positivistic elucidation of truth; and to what degree they might perceive it as socially and politically constructed, "normal" or "revolutionary" in the Kuhnian sense, methodologically "messy" as Feyerabend suggests, or a continuing pursuit of an ever-elusive truth in the Popperian sense. Indeed, the nature of science should be a conscious part of every instructor's discourse.

\section{Developing Dispositions Toward Science}

Instructors in all courses should be encouraged to consider the dispositions towards science their courses develop in students. What, for example,are the gender implications of the content of courses, and of the way in which courses are structured and presented? What view of science is portrayed in textbooks, laboratories, and classrooms? How can science be portrayed in ways that will interest all students, whether male or female, or intended for a career in science or not?

\section{A Collaborative Proposal for a New Honours B.Sc. Program}

\section{Description of the New Program}

The new Honours B.Sc. program proposed for the Faculty of Science at the University of Western Ontario is an interdisciplinary program that permits a broader selection of courses and a more comprehensive introduction to science than is offered in other more subject-specialized programs. In addition to nine full courses in a major field of study, and up to four in a minor, the new program will offer students courses in Earth-Planetary and Space Science, Environmental Science, and "Frontiers" of Science (half-courses in biology, chemistry, physics, the mathematics of science, and statistics and computers). The program will include a full course in "Science Studies" (history and philosophy of science, societal issues, communication of science), two full courses in English or French or a foreign language, and a full course in Mathematics, as 
well as various options and tutorials, a summer field experience related to an area of study, and a senior thesis.

The Science Studies course, the Environmental Science course, and the Frontiers series in particular are intended to provide a focus on science-related social issues. The Science Studies course is also intended to provide an introduction to epistemological questions in science, an area largely neglected in most other science courses and programs. While the balance among the components of the program, and the emphasis in the content of some of the courses, may ultimately remain a matter of concern for those who would prefer a more profoundly critical and socially responsive science curriculum, there is no doubt that what is proposed represents a major step forward in honours science programs at this university.

\section{Collaboration with the Faculty of Education}

A unique feature of the proposed program is that it will be planned and administered by an Advisory Board with members drawn from both the Faculty of Science and the Faculty of Education, and from local secondary and elementary schools. The involvement of classroom teachers as well as teacher educators in the administration of the program will, it is hoped, help to ensure that a conscious commitment is maintained to a program that is not only academically rigorous and epistemologically sound, but attractive to a wider range of students. Through the leadership and work of the Advisory Board, educational research might be brought to bear on the design, content, and presentation of the new program. Plans are to be developed, for example, for facilitating Faculty of Science access to and interpretation of relevant research, and for reflecting on the way science is presented and portrayed in various parts of the science program.

Several components of the new program might be taught by members of the Faculty of Education:

Tutorials. Proposed as a non-credit component, mandatory after Year One, the tutorials offer a forum for discussion of epistemological issues, social aspects of science, career opportunities, and so on. A special section might be offered for students considering careers in education.

Summer field experience. Offered after Years Two and Three, the Field Experience is intended as an opportunity for students to acquire experience in jobs related to their current or intended field of study. Opportunities in education are limited during the summer, but placements in schools in May and June, and in Outdoor Education facilities throughout the summer, are feasible.

Senior thesis. Under the direction of members of the Faculty of Education, fourth year students may elect a topic on teaching and learning in science. 


\section{Program Evaluation and Research}

The process of "illuminative evaluation" (Parlett \& Hamilton, 1977), an action research approach to program evaluation designed specifically for the study of new and innovative programs, will be used to inform, document, and examine the development and implementation of the new Honours B.Sc. Illuminative evaluation acknowledges that program development is immensely complex, and that contextual and situational factors are significant to both process and results. In other words, neither the form nor the implementation of the new program can be fully determined in advance; to some degree, it must be created in process. Illuminative evaluation also acknowledges the difference between the instructional system--the program as described on paper, and which itself has a complex history--and the learning milieu--"a network of cultural, social, institutional and psychological variables...[that] interact in complicated ways to ...[affect] teaching and learning" (Parlett \& Hamilton, 1977, p. 11). Evaluation of the new Honours B.Sc. program will include consideration of

a) the instructional system (the program itself and constituent courses):

- nature and structure of the new program; how it differs conceptually and epistemologically from other science programs;

- processes through which the program is developed and implemented;

- institutional and personnel factors affecting program development;

b) the learning milieu (environments in which students and instructors work):

- effects of the new program on what and how instructors teach;

- effects of the new program on students' experiences of science, development of subject-matter knowledge, and views of and attitudes towards science;

c) effects on the institution and beyond:

- how the new program is perceived both within and outside the Faculty; 
- effects on educational policy within the Faculty;

- effects on policy and programs outside the Faculty, most particularly in the Faculty of Education;

- effects on enrollment and retention of students in science.

\section{Significance of the Project}

The development and evaluation of a new, interdisciplinary Honours B.Sc. has the potential to inform program development and policy formation beyond the bounds of one faculty of science. The most successful aspects of the new program and of the collaborative endeavour may interest other faculties of science and other faculties of education. Indeed, "research on innovation can be enlightening...to the whole academic community by clarifying the processes of education and by helping...to identify those procedures, those elements in the educational effort, which seem to have had desirable results" (Parlett and Hamilton, 1977, p. 10, quoting Trow).

Although only a relatively small part of the Canadian population may ever enroll in university science programs, those who do so go on to influence many others. In particular, those who go on to become science teachers may, during their teaching careers, influence thousands. Improving the quality of science programs offered in Canadian schools and universities, and the quality of the teaching offered there, is probably one of our best hopes for advancing scientific "literacy" and science culture in Canada.

\section{A Final Comment on Inter-faculty Collaboration}

A recent conference brought together deans and professors of arts and science, and of education, "to talk about undergraduate education and teacher education, what happens in each, how they relate to each other, and how, perhaps, something somewhere might be changed for the better" (Van Fossen, 1990, p. 1). Bernard Shapiro, a former dean of education and deputy minister of education, expressed his dismay that this sort of communication and interaction was only beginning to happen 25 years after the transfer of faculties of education in the province (Ontario) to the universities: "Where the hell have you people and your institutions been all this time?" he asked in his closing remarks to the assembly (Shapiro, in Van Fossen, 1990, p. 56).

Indeed, an opportunity for a faculty of science and a faculty of education to collaborate in designing an undergraduate science program is an opportunity not to be missed. Those who will benefit most directly and immediately are 
instructors and undergraduate students in the Faculty of Science at the University of Western Ontario, but prospective science teachers, teacher educators, curriculum developers, and, ultimately, students in science programs in schools across the province also stand to benefit as the new program is established.

\section{Notes}

1 Others would argue that although a grounding in a subject area characterizes a subject specialist, other kinds of knowledge characterize teachers. Lee Shulman (1987), for example, has suggested that teachers require not only specialized subject knowledge but "pedagogical content knowledge, that special amalgam of content and pedagogy that is uniquely the province of teachers, their own special form of professional understanding" (p. 8).

\section{References}

Ainley, M.G. (1990). Despite the odds: Essays on Canadian women and science. Montreal: Vehicule Press.

Ball, D., \& McDiarmid, G. (1990). The subject-matter preparation of teachers. In W.R. Houston (Ed.), Handbook of research on teacher education (pp. 437-449). New York: Macmillan Publishing Company.

Brumby, M. (1981). Misconceptions about the concept of natural selection by medical biology students. Science Education, 68, 493-503.

Champagne, A.B., Gunstone, R.F., \& Klopfer, L.E. (1985). Effecting changes in cognitive structures among physics students. In L.H.T. West \& A.L. Pines (Eds.), Cognitive structure and conceptual change (pp. 163-187). New York: Academic Press.

Clement, J., Lochhead, J., \& Monk, G.S. (1981). Translation difficulties in learning mathematics. American Mathematical Monthly, 8, 286-290.

Cros, D., et al. (1986). Conceptions of first-year university students of the constituents of matter and the notions of acids and bases. European Journal of Science Education, 8, 305-313.

Erickson, G.L., \& Erickson, L.J. (1984). Females and science achievement: Evidence, explanations, and implications. Science Education, 68(2), 63-89.

Fciman-Nemser, S. (1990). Teacher preparation: Structural and conceptual alternatives. In W.R. Houston (Ed.), Handbook of research on teacher education (pp. 212-233). New York: Macmillan Publishing Company.

Geddis, A.H. (1990, Junc). The tyranny of the "right answer": The systematic distortion of scientific knowledge. Paper presented at theAnnual Conference of the Canadian Socicty for the Study of Education, Victoria, British Columbia.

Gorodetsky, M., \& Hoz, R. (1985). Changes in the group cognitive structure of some chemical equilibrium concepts following a university course in general chemistry. Science Education, 69, 143-152. 
Haggerty, S. (1991). Toward a gender-free science in schools. In L.J. Rennie, L.H. Parker, \& G.M. Hildebrand, Action for Equity: The Second Decade, Volume 1, pp. 401-407. Perth, Australia: National Key Centre for School Science and Mathematics.

Harding, S., \& O'Barr, J.F. (Eds.). (1987). Sex and scientific inquiry. Chicago: The University of Chicago Press.

Harris, W.F. (1981). Heat in undergraduate education, or isn't it time we abandoned the theory of caloric? International Journal of Mechanical Engineering Education, 9(4), 317-321.

Hodson, D. (1986). Philosophy of science and science education. Journal of Philosophy of Education, 20(2), 215-225.

Kahle, J.B. (Ed.). (1985). Women in science: $A$ report from the field. Philadelphia: The Falmer Press.

Keller, E.F. (1985). Reflections on gender and science. Hew Haven: Yale University Press.

Linder, C.J., \& Erickson, G.L. (1989). A study of tertiary physics students conceptualizations of sound. International Journal of Science Education, 11, 491501 .

McDermott, L.C. (1984, July). Research on conceptual understanding in mechanics. Physics Today, 24-32.

Parlett, M., \& Hamilton, D. (1977). Evaluation as illumination: A new approach to the study of innovatory programmes. In D. Hamilton et al (Eds.), Beyond the numbers game: $A$ reader in educational evaluation. Basingstoke: McMillan.

Shulman, L.S. (1986). Those who understand: Knowledge growth in teaching. Educational Researcher, 15(2), 4-14.

Van Fossen, R. (Ed.). (1990). To make a difference: Teacher education for the 1990s. Proceedings from a COU-sponsored conference on teacher education. Toronto, Ontario: Council of Ontario Universities. 